\title{
COMPREHENSIVE STUDY AND MONITORING PROGRAM FOR BEACHES AT VIÑA DEL MAR CHILE
}

\author{
Benjamín Carrión, PRDW, bcarrion@prdw.com \\ Rolando García, PRDW, rgarcia@prdw.com
}

\section{INTRODUCTION}

On August $8^{\text {th }} 2015$, an extreme storm event affected central Chile. Significant wave heights up to $5.0 \mathrm{~m}$ at a depth of $20 \mathrm{~m}$ were estimated in front of Viña del Mar. Beaches suffered massive erosion and relevant damage to coastal infrastructure occur (Figure 1), jeopardizing the touristic industry of the city.

These episodes motivated the execution of the largest comprehensive study and monitoring plan ever done on the littoral system of Viña del Mar. The study considered reviewing historical records, hydrological analysis of the related river basins, several bathymetric and topographic surveys, sediment samples, measurements of waves and currents, monitoring cameras for field recording and extensive numerical modelling.
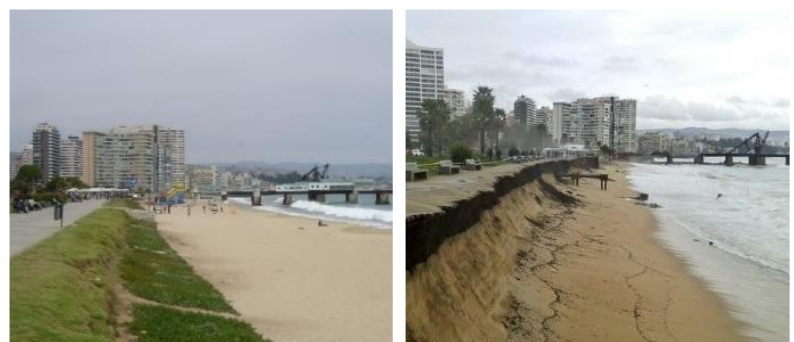

Figure 1 - Playa El Sol, Viña del Mar, before (left) and after (right) storm event of 2015/08/08.

\section{OVERVIEW OF THE LITTORAL SYSTEM}

Typical incident wave conditions arriving at Viña del Mar correspond to swell waves of 12-16 s generated in the Southern Pacific. The wave climate induces a moderate net longshore sediment transport towards the North, which distributes sediment provided by Marga Marga river to most of the beaches in the system.

During winter storm events, waves of shorter period typically arrive from the Northwest, which drive intense longshore sediment transport towards the South.

The combination of these two transport rates result in a small net northerly transport, which is consistent with the only occasional sediment supply of Marga Marga river and confirms the dynamic equilibrium state of these beaches, in line with historical reviewed records and complementary analysis carried out.

This seemingly simple mechanism helps explaining the overall dynamics of the littoral system but turns out to be extremely simplified to address the dynamics of each beach of the system, as it does not account for other temporal and spatial variations triggered by hydrodynamic cells that ultimately drive the morpho dynamics of each unit.

In addition, relevant cross-shore sediment transport during winter storm events have been registered. Current surveys also showed fast recovery of these beaches from cross-shore eroded condition. Beach recovery after winter season is a key issue for touristic industry in Viña del Mar.
Beach berm recovery rate was calculated for all units in terms of the beach berm eroded volume. It was found that the larger the erosion the higher recovery rate.

\section{NUMERICAL MODELLING}

Cross-shore sediment transport was examined with CSHORE by Kobayashi (2013). Calculated erosion after registered storm events at different beaches of this littoral system showed good agreement with field measurements. Use is made of $\mathrm{XBEACH}$ by Roelvink (2009) to analyze spatial distribution of sediment transport after winter storm events. The results of this modelling could help allocating sandbanks and allow to optimize the resources designated to beach recovery before each touristic season.

\section{CURRENT STATE OF THE LITORAL SYSTEM}

Contrary to findings by Martinez et. al. (2017), no significant evidence of local wave climate change was observed among the reviewed period 1979 - 2017, neither on wave parameters such as $\mathrm{H}_{\mathrm{m} 0}, \mathrm{~T}_{\mathrm{p}}$, and $\mathrm{D}_{\mathrm{m}}$, nor on the number of extreme storm events per year. The significant recession experienced by certain beaches of this littoral system since 2003, especially those located immediately north of Marga Marga river mouth such as Acapulco Beach (Figure 2), showed no consistent relation with wave climate.
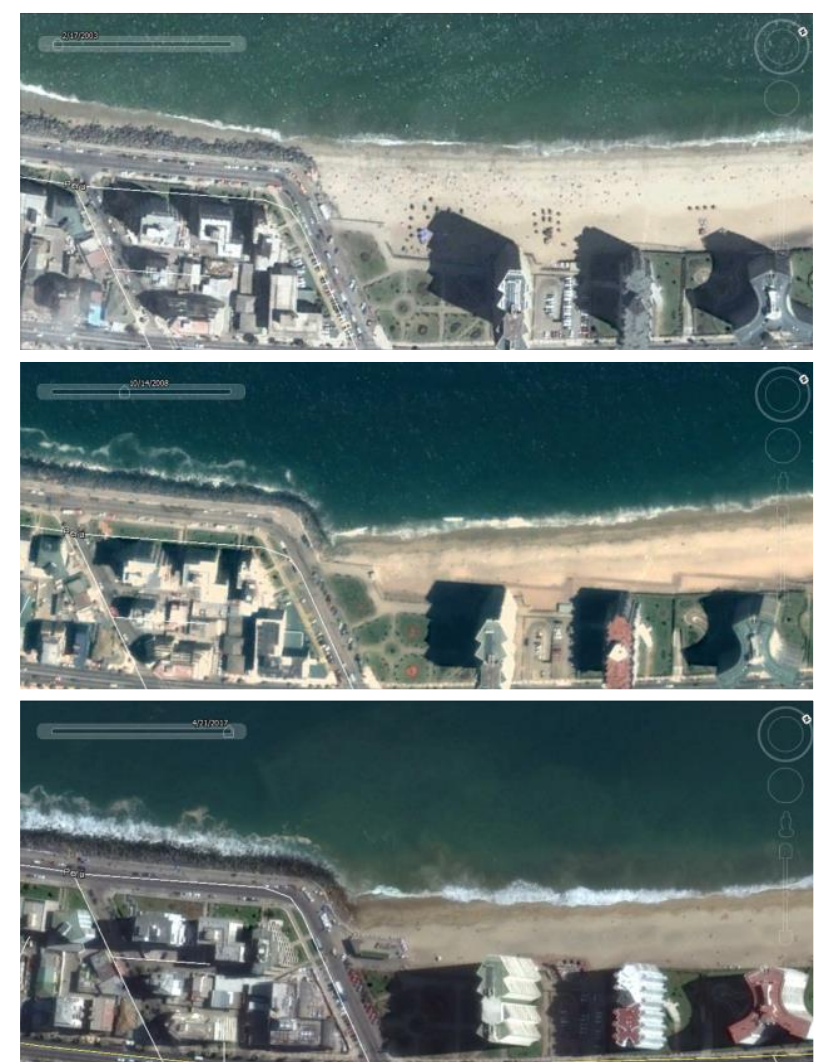

Figure 2 - Aerial photographs of Acapulco Beach on 02/2003, 10/2008 and 04/2017. 
Instead, this recession seems to be closely related with an unusual sediment supply due extreme flood events of Marga Marga river, occurred in 1997, 2000 and 2002, followed by a period with no relevant floods until today. Such diagnosis was confirmed with a hydrological numerical simulation of the the Marga Marga river basin, using measured daily precipitation from 1975 to 2015 . Results of this analysis are shown in Figure 3, where the calculated bedload sediment supply from 1995 to 2015 is shown. An excess of sediment supply is verified on year 2003, while on the most recent years, sediment supply seems to be below the average trend.

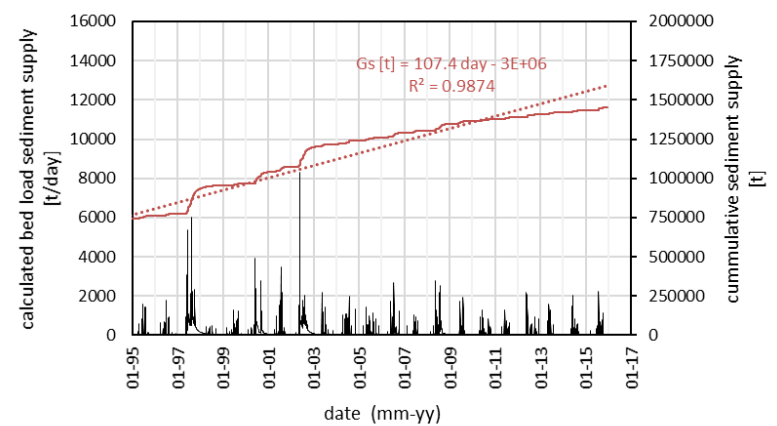

Figure 3 - calculated sediment supply (bed load) by Marga Marga river between 1995 - 2015.

\section{CONCLUSIONS}

This study reflects the importance of conveying an integrated analysis that comprises not only littoral processes but also hydrological ones. The littoral system of Viña del Mar seems to be in dynamic equilibrium, but currently facing a lack of sediment supply from the Marga Marga river.

\section{REFERENCES}

Kobayashi, N. (2009). "Documentation of cross-shore numerical model CSHORE 2013." Res. Rep. No. CACR13-01, Center for Applied Coastal Research, Univ. of Delaware, Newark, DE.

Martinez, C. et al. (2017): Coastal erosion in central Chile: A new hazard?, Ocean \& Coastal Management, ELSEVIER, vol. 156, pp. 141-155.

Roelvink, Reniers, van Dongeren, van Thiel de Vries, McCall, Lescinski (2009): Modelling storm impacts on beaches, dunes and barrier islands, Coastal Engineering, ELSEVIER, vol. 56, pp. 1133-1152. 